\title{
Supporting Digital Scholarship in the
}

\section{Academic Library}

\section{Stephanie Savage}

University of British Columbia, Vancouver, Canada

\begin{abstract}
As academic libraries shift their focus toward supporting digital scholarship, recent MLIS graduates and early career librarians are being asked to bring new skillsets to their positions, yet opportunities to obtain these requisite skills are still lacking.
\end{abstract}

Author Bio: Stephanie Savage is a Scholarly Communications and Copyright Services Librarian at the University of British Columbia. In her role she provides copyright education to faculty, students, and staff and supports various campus initiatives to encourage and promote the adoption of open practices and research products.

Keywords: digital scholarship, technology training, research support

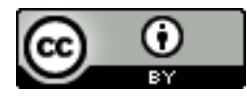

This is an Open Access article distributed under the terms of the Creative Commons Attribution 4.0 International License (http://creativecommons.org/licenses/by/4.0), which permits unrestricted use, distribution, and reproduction in any medium, provided the original work is properly cited. 
As a fairly recent graduate of an MLIS program who has just over one year of professional experience in an academic library environment, I am familiar with both the course of study that students undertake in preparing for their professional careers, as well as the needs and expectations that institutions have for their incoming librarians. As academic libraries reposition themselves as research support centers, and try to shake their outdated image as book storage facilities, these expectations have continued to shift (Schmidt, Calarco, Kuchma, \& Shearer, 2016). What I have noticed in making the transition from student to professional is that many of the skills required to fulfill emerging positions in the library are not being taught to students or early-career librarians. When they are, it is only at the theoretical, and not practical, level. Specifically, the growing focus on digital scholarship and evolving research practices has revealed a skills gap that may be preventing libraries from fully exploiting new opportunities to support the research lifecycle (Research Libraries UK, 2012). More importantly, it may prevent participation in the research process on their campuses.

A quick review of current postings on the American Library Association JobLIST (https://joblist.ala.org) reveals a multitude of positions ("Librarian for Emerging Technology and Digital Projects," "Digital Scholarship Librarian,” "Data Curation Librarian," “Digital Pedagogy Librarian”) that require explicit digital and/or technological skills, as well as an additional set of the "traditional" skills more typical of liaison positions. These positions necessitate familiarity with both digital methodologies and services. Although these examples are far from conclusive, they serve to illustrate my general point that academic librarians are increasingly being asked to bring a technologicallyoriented skillset to their positions.

Given the need for these skills, it is important to ask where librarians will obtain them. While some may be coming into the profession with these skillsets, I think it is safe to assume that the vast 
majority of MLIS students expect to receive this necessary training as part of their course of study. In my experience however, MLIS programs introduce students to emerging needs and areas of opportunity for development within the field, but they don't provide enough hands-on training in digital project creation or processes. Programs need to provide more space for students to participate in digital projects, as direct experience is what will best prepare them for the emerging job market. Learning how to mark up texts in XML or visualize data on maps, for example, are tangible skills that students can communicate to employers, demonstrating not only an awareness of evolving technical skillsets but also an ability to obtain and master them.

I am, of course, not the first to notice the need for librarians to be "technologically-savvy" (CARL, 2010) and some new paths forward are beginning to emerge. On the national and international level workshops and institutes including THATCamps, the ARL Digital Scholarship Institute, and Library Carpentry are creating librarian-focused programs that provide opportunities to tinker and play with technology while at the same time framing digital scholarship within the academic library. Other researcher-focused events, such as the Digital Humanities Summer Institute, are also becoming increasingly inclusive of librarians. While these opportunities are certainly a move in the right direction, more can be done to ensure that the next generation of librarians are able to meet shifting demands and opportunities within academic institutions. One strategy is for academic libraries themselves to continue creating new opportunities for MLIS students and early-career librarians, which would allow them to work on digital projects within the library (Munoz, 2012). This is an ideal solution, as librarians not only need to know about the tools, but also need to work with them. Library-created and led projects would provide the best training opportunity for skill development in these areas. This seems to be a sentiment shared by Indiana University Bloomington and Columbia University, which have 
adopted the library-led approach to digital scholarship skills training with their Research Now (https://blogs.libraries.indiana.edu/iulrn) and Developing Librarian Projects

(https://devlib.library.columbia.edu/the-developing-librarian-project-columbia-university-librarians), respectively.

The next steps for programs like those at Indiana University and Columbia University, and any other libraries beginning to consider similar programs are to ensure that the training doesn't stop with professional librarians, and that it is also extended to students. In the same vein, MLIS programs should look for opportunities to partner with their institutional libraries, promoting hands-on experience as much as possible with their students. If both libraries and MLIS programs do their part to advocate for technological-oriented learning by creating their own opportunities to do so, the profession will surely be better poised to meet current needs, while simultaneously positioning itself as a strong and legitimate research collaborator to faculty.

\section{References}

Canadian Association of Research Libraries. (2010, October). Core competencies for $21^{\text {st }}$ century CARL librarians. Belzile, S., Busby, L., Delong, K., Garnett, J., Haines, M., Ingles, E., ... McColgan, K. Retrieved from https://www.carl-abrc.ca/doc/core comp profile-e.pdf

Munoz, T. (2012, August 19). Digital humanities in the library isn't a service. Trevormunoz.com. Retrieved from http://trevormunoz.com/notebook/2012/08/19/doing-dh-in-the-library.html

Research Libraries UK. (2012). Re-skilling for research: An investigation into the role and skills of subject and liaison librarians required to effectively support the evolving information needs of 
researchers [Draft report]. M. Auckland. Retrieved from http://www.rluk.ac.uk/wpcontent/uploads/2014/02/RLUK-Re-skilling.pdf

Schmidt, B., Calarco, P., Kuchma, I., \& Shearer, K. (2016). Time to adopt: Librarians' new skills and competency profiles. In F. Loizides \& B. Schmidt (Eds.), Positioning and power in academic publishing: Players, agents and agendas (pp. 1-8). Retrieved from http://ebooks.iospress.nl/publication/42887 